\title{
The "new regionalism" and the Free Trade Area of the Americas: a less benevolent view
}

\author{
Roberto Bouzas
}

ก

his paper examines the pros and cons of the "new regionalism", taking as a landmark the negotiations for a Free Trade Area of the Americas (FTAA). It summarizes the main features of the "new regionalism" and reviews some of the challenges and opportunities opened up by North-South preferential trade agreements (a category that includes many of the new vintage of such agreements). It underlines the role of domestic policies as a complement to trade liberalization, an aspect generally overlooked in the debate about trade negotiations and preferential trade agreements. It reviews the record of the FTAA negotiations, emphasizing recent trends and prospects. Lastly, it summarizes the main points raised and emphasizes the problematic features of the FTAA that is starting to emerge after a decade of San Andrés, Buenos Aires Senior Research Fellow, National Science and Technology Council (CONICET), negotiations. 


\section{I}

\section{Introduction}

Preferential trade agreements (PTAs) have mushroomed in the Western Hemisphere since the mid-1980s. After two decades of active negotiations, the final architecture of this network of preferential trade pacts is still in the making. The proliferation of PTAs in the region is not entirely new, but the latest vintage of trade discrimination differs in several ways from that of the past and this has caused it to be labelled the "new regionalism". ${ }^{1}$

Whether convinced of its beneficial effects or of its inevitability, many analysts have evaluated the "new regionalism" benevolently, emphasizing the potential advantages and minimizing the costs. Only a handful of "free-traders" — usually accused of lacking "practical sense" - have consistently raised a critical voice.

The objective of this paper is to examine the pros and cons of the "new regionalism", taking as a landmark one of its most significant and complex manifestations, the negotiations to establish a Free Trade Area of the Americas (FTAA). The problems that have emerged in relation to the architecture and regulatory content of the FTAA are indicative of the challenges and opportunities offered by the new vintage of trade discrimination. A hemisphere-wide preferential agreement may create trade opportunities for the Latin American countries and foster economic development throughout the continent, but this will not come about automatically. The opportunities that may be opened by the FTAA - like those stemming from any process of economic liberalization - are conditional. If they are to materialize, the agreement must meet certain conditions and be accompanied by policies that make it possible to reap the benefits of increased competition, larger markets and deeper specialization. Seen in this framework, the FTAA negotiations display worrying trends.

This paper has five sections. Following the present introductory section, section II summarizes the main features of the "new regionalism" and reviews some of the challenges and opportunities opened up by North-South PTAs (a category that includes many of the new vintage of such agreements). Section III underlines the importance of domestic policies to complement trade liberalization and the vital role these play when it comes to actually reaping the opportunities offered by the "new regionalism", an aspect generally overlooked in the debate about trade negotiations and preferential trade agreements.

Section IV reviews the FTAA negotiations to date, emphasizing recent trends and future prospects. Section $\mathrm{V}$, lastly, summarizes the main points raised in the paper, with comprehension rather than prescription as its aim.

\section{The "new regionalism" and North-South preferential trade agreements in the Western Hemisphere}

The wave of preferential trade negotiations that has swept over the Western Hemisphere in the last two

$\square$ I am grateful for the valuable comments made by an anonymous reviewer.

1 At the southern end of the Western Hemisphere the "new regionalism" was inaugurated by the Argentine-Brazilian Trade and Cooperation Programme signed in 1986 (a precursor to Mercosur). At the northern end the first agreement was the United States-Canada Free Trade Agreement (FTA). decades has been a key ingredient of the so-called "new regionalism". ${ }^{2}$ This process has resulted in a complex

\footnotetext{
2 The "new regionalism" is now worldwide. Even the Asia-Pacific region, which had traditionally stood aside from discriminatory practices, has joined the global trend, as suggested by the preferential pacts signed by Japan, the Republic of Korea and Singapore. For an early analysis of the characteristics of the "new regionalism", see Bouzas and Ros (1994); see also IDB (2002) and Torrent (2002).
} 
web of PTAs that Baghwati (1993) has likened to a "spaghetti bowl". Although at first sight, at least in Latin America, it does not look very different from the "old regionalism", the "new regionalism" has been accompanied by changes in both context and content. The contextual changes include a more outwardoriented policy environment (as a result of unilateral and multilateral liberalization) and a renewed emphasis on promoting closer integration into the world economy (in contrast to the "autarchic" policies prevalent in the past). The most significant changes in content include broader coverage of issues and disciplines (a "deeper" agenda) and the emergence of North-South agreements binding together national economies with large disparities in per capita income. These new features may increase liberalization commitments, but also friction between divergent regimes and standards of treatment. In the "new regionalism" the developed countries have also become active contributors to the "spaghetti bowl". The most prominent case, because of its systemic role and its decisive contribution to the creation of the post-war multilateral trading regime, is that of the United States, which after decades of championing multilateralism has embraced discrimination as a complementary policy. ${ }^{3}$

The "new regionalism" has certain advantages over the PTAs of the past. Some of these have to do with the new trade policy environment, such as the fact that more outward-oriented trade policies have lowered the welfare costs of trade diversion for members and of negative discrimination for non-members. Others, however, relate to the specific content of the "new regionalism". A number of analysts have pointed out that North-South PTAs give smaller and less developed economies preferential access to large high-income markets. This benefit cannot be obtained through unilateral liberalization and is shared with others when liberalization is the result of multilateral bargaining. Under some circumstances, preferential access to large markets can be a powerful driving force for developing-country exports. Similarly, the broader coverage of disciplines typical of the "new regionalism" may provide the developing-country partner with more stable market access conditions. This is particularly important because of the type of

\footnotetext{
3 The European Community has had a tradition of activist preferential trade policies towards developing countries, largely as a result of the European colonial past.
}

protectionist instruments typically used in industrial countries, such as "administrative protection", sanitary standards, etc. North-South agreements can also be a vehicle for improving expectations, conferring greater certainty upon the policy regime and attracting larger flows of foreign investment into countries that usually face severe balance-of-payments constraints (Ethier, 1998; World Bank, 2000). Moreover, some authors point out that they can encourage (or even "force") developing countries to adopt institutions prevalent in the developed partner, thus helping them to improve economic performance. ${ }^{4}$

To deliver these results, which are not automatic, North-South arrangements must respond adequately to at least four challenges: ensuring effective reciprocity; ${ }^{5}$ helping to cope with adjustment and transition costs; preventing the consolidation of polarization dynamics; and ensuring that institutional spillovers have a positive effect and can be effectively appropriated by the developing partner. None of these can be taken for granted, and they should thus be explicitly addressed in any North-South agreement.

Although the issue of reciprocity is critical, the historical evidence shows that it has not been easy to enforce in the multilateral trading system, including the Uruguay Round that ended in 1994. In fact, although agriculture was included within the general disciplines of the General Agreement on Tariffs and Trade (GATT) and the parties agreed to phase out quantitative restrictions on trade in textiles and garments, the Marrakesh Agreement establishing the World Trade Organization (WTO) and the implementation process that followed have generated widespread dissatisfaction in the developing world. There is now a growing consensus that in some fields, such as the protection of intellectual property rights and the enforcement of trade-related investment disciplines, the developing countries accepted commitments without being fully aware of their impact and implications, making reciprocity virtually impossible.

Taking into account the precedents at the multilateral level, it may be worth asking what factors may increase the likelihood of North-South preferential pacts being negotiated in a more balanced way. As a matter of fact, several structural features of the North-

\footnotetext{
${ }^{4}$ See Schiff and Winters (2003).

${ }^{5}$ Reciprocity is the policy whereby governments grant one another concessions deemed equivalent in some way (for example, one of them reduces tariff or other barriers to imports in exchange for the trading partner making equivalent concessions in its export barriers).
} 
South variety of regional integration may work the other way and hinder reciprocity. First, industrial countries typically have well-established democratic institutions that give citizens' votes greater weight in the domestic political process than is usually the case in the developing world. Partly as a result, legislatures in industrial democracies tend to play a more substantive role in policy design and to be more effective at transmitting private-sector interests (collective or otherwise). This feature of the policy process is reinforced by the fact that in the industrial countries the private sector tends to be better organized and to identify and promote its strategic interests more effectively than in developing countries. In the latter the private sector tends to organize more around "defensive" issues that provide only a fragile basis for the construction of an "offensive" bargaining agenda. Non-business actors in industrial countries also tend to have a more active and informed role in the policymaking process, raising the likelihood that their views and interests will be reflected in the final deal.

The chances of North-South preferential negotiations leading to more reciprocal outcomes are also negatively affected by the fact that some issues which are very sensitive for a number of developing countries are the outcome of the interplay of forces in the global political economy. This being so, it is unclear how preferential negotiations can make substantial progress towards more balanced trade agreements. ${ }^{6}$ Examples of these sensitive issues are domestic subsidies for temperate agricultural products and the implementation of "trade relief", especially antidumping duties. In effect, a cursory examination of existing North-South preferential arrangements confirms that these issues were left untouched by the negotiators.

The likelihood that North-South preferential arrangements will be based on reciprocity is also shaped by the dynamics of the bargaining process (outcomes are "path dependent"). Political economy considerations suggest that one factor influencing industrial countries' choice of partners for negotiating preferential trade arrangements is the minimization of

\footnotetext{
${ }^{6}$ North-South PTAs (such as the North American Free Trade Agreement or the free trade agreements between the European Union and Mexico and Chile) have been carefully drafted to avoid touching on issues that are very sensitive for the developed-country partner (such as temperate agriculture in the case of the European Union). Although this may be an acceptable bargain for some developing countries, it may be extremely inefficient for others.
}

transition and adjustment costs (and hence of domestic political opposition). In an asymmetrical context this will increase the probability that the agreement will reflect the priorities and sensitivities of the more powerful partner. If an industrial country signs successive agreements with one developing country at a time, these are very unlikely to be based on reciprocity. In addition to the effects of this bargaining path on the regulatory content of successive agreements, the "exclusion costs" for outsiders will increase pari passu with the expansion of the preferential network (either through a "minilateral" arrangement or a "hub-and-spokes" system). In the present context of uncertainty as to the evolution of the multilateral trading regime, the resulting "defensive incentives" may make the costs of non-participation (even in a non-reciprocal deal) economically and politically unbearable. The increase in perceived "exclusion costs" may raise the price of the "entry ticket", reducing further the likelihood of reciprocal and balanced agreements. ${ }^{7}$

North-South preferential trade agreements can be a vehicle for improving expectations, providing policy regimes with greater stability and attracting larger inflows of foreign investment to developing countries. They may also encourage a developing country to upgrade its existing institutions and adopt some of those commonly found in developed countries, thus improving economic performance. But these benefits are less automatic than is presumed by the more enthusiastic proponents of North-South regionalism. More stable policy regimes will be good only if the underlying policies are sound and sustainable. Moreover, although economic integration with a developed country can trigger institutional modernization, the "importation" of institutions is rarely the best way to proceed, not least because the efficacy of alternative institutional arrangements is contingent on the environment in which they operate (Lawrence, 1999). This is not to deny that institutional effects may be positive, but to underline that much will depend on the particular circumstances and on the domestic environment and policies. Moreover, some foreign institutions (or regimes) may simply run

\footnotetext{
7 These perverse dynamics are not taken into account by the tautological argument often used to explain away the behaviour of developing-country governments in respect of North-South agreements, namely that "if they participate voluntarily, it must be because they benefit".
} 
counter to the economic or policy interests of the developing-country partner. ${ }^{8}$

Transition and adjustment costs in the developing country are a third key issue for North-South regionalism. Like any liberalization process, preferential liberalization will require the parties to cope with these costs. When factor endowments differ greatly between the partners, as is usually the case in North-South agreements, the resulting specialization pattern will be largely inter-industry. Consequently, relative prices and factor payments will experience comparatively large changes. ${ }^{9}$ These changes, furthermore, will be bigger in the smaller partner. Conventional trade theory treats this outcome as evidence that most of the gains from trade liberalization will accrue to the smaller economy. However, although inter-industry specialization offers the potential for large efficiency gains, these gains are conditional and if they materialize they will do so only in the long term. During the transition, national economies will need to cope with the costs of adjustment.

This time-consistency challenge is a major political economy problem, but one that receives relatively little attention in conventional international trade theory. It is also a major issue for policy makers in the real world. The intense debates that took place in the United States Congress when it was considering NAFTA (a treaty that involved Canada, Mexico and the United States) and, more recently, when it passed the Trade Promotion Authority (TPA) Act are illustrative of the attention that the treatment of transition and adjustment costs mobilizes in the case of industrial countries. ${ }^{10}$ These issues are even more important for developing countries, where adjustment costs are typically larger and where less financial, political and institutional resources are available to cope with their consequences. If this issue is not addressed cooperatively, it may deepen existing

\footnotetext{
${ }^{8}$ Protection for intellectual property rights as originally established by the Trade-Related Aspects of Intellectual Property Rights (TRIPS) Agreement was problematic for many developing countries, something that was officially acknowledged after much diplomatic activism in the area of public health.

${ }^{9}$ Intra-industry or intrasectoral specialization is less resisted than inter-industry specialization because it is usually accompanied by less significant relative price changes. This, in turn, means more modest changes in production factor payments and income distribution.

${ }^{10}$ As well as defining precisely what trade negotiating objectives should be pursued by the United States Administration, the TPA was passed simultaneously with a package of financial resources to provide social security benefits to workers left unemployed by higher imports.
}

asymmetries by enabling the developed-country partner to deal more effectively with its own adjustment costs or even transfer some of the burden to the developingcountry partner.

Finally, market and policy failures can help transmute adjustment and transition costs into polarization dynamics and path divergence. NorthSouth preferential arrangements offer opportunities for convergence in per capita income levels between rich and poor countries, but they may also consolidate vicious circles of stagnation and decay. As a matter of fact, there is no theoretical reason why one trajectory should predominate over the other. While some authors emphasize the forces for convergence (World Bank, 2000), others underline the persistence of divergent economic performances over time (this is the case with cumulative causation models and endogenous growth theories). ${ }^{11}$ In the latter case, "polarization effects" could heighten existing inequalities and make preferential trade agreements economically and/or politically unsustainable, unless active public policies are adopted.

In developing countries, failures in financial, information and technology markets are frequent. In addition, there are widespread policy failures due to the relative fragility and newness of democratic institutions and the weakness of their administrative capabilities. In this context, the forces for convergence may be too weak. With per capita income disparities much smaller than those prevailing in the Western Hemisphere, the European Union has made intensive use of structural and regional funds to promote cohesion and counteract the forces of polarization. The available evidence suggests that apart from the contribution made by financial transfers (which is debatable), the upgrading of local institutions has played a key role.

In summary, the "new regionalism" has advantages as compared to the typical PTAs of the past (many of them related to the broader trade policy environment), but it also faces new challenges that make clear-cut conclusions about its superiority hard to sustain. Many of the challenges and opportunities typical of trade discrimination are magnified in NorthSouth agreements. This ambiguity lurks in the background of most analyses, but its implications are rarely developed in full. Under some circumstances the "new regionalism" can bring tangible benefits for a

\footnotetext{
${ }^{11}$ See Bouzas (2003) for a discussion of the effects of structural and policy asymmetries on economic integration.
} 
developing country (such as rapid manufacturing export growth in the case of Mexico). However, the nature and extent of these benefits will be contingent on the content of the agreement, the bilateral agenda, the structural characteristics of the partners and domestic policies. These qualifications sound quite obvious, but they have been downplayed in the past and it is only recently, as evidence of the difficulties has emerged, that they have begun to occupy a more visible place in the public policy debate.

Going beyond the national focus, one should emphasize that for outsiders the impact of the "new regionalism" (especially North-South agreements) is likely to be negative. The resulting "defensive incentives" may distort policy decisions and make the playing field even less level that it was before. Evaluating the consequences of this process from a "cosmopolitan" perspective - rather than a purely national one- is a difficult task, but one that must be attempted if the impact of the "new regionalism" is to be properly assessed. Much of the inconclusive debate about whether regionalism is a stepping-stone or a stumbling-block for multilateralism bears on this issue, which is not theoretical but empirical.

\section{III}

\section{The role of domestic policies}

Preferential trade agreements, particularly North-South ones, provoke strong reactions for and against. The resulting debate generally assigns only secondary importance to what is after all the key to reaping the potential benefits of economic integration: domestic policies. Trade liberalization (be it preferential, multilateral or unilateral) may increase efficiency, foster productivity growth and contribute to economic development, but it is not a sufficient condition for growth and development, as the simplistic policy recommendations prevailing in the 1990s suggested. Similarly, economic integration and North-South preferential agreements may encourage growth and development, but that will depend on the content of the agreement and the accompanying domestic policies.

During the 1990s many Latin American and Caribbean countries implemented ambitious trade liberalization programmes, but most of them did not experience any significant improvement in economic performance, as measured either by real output or by export growth. ${ }^{12}$ The potential benefits of trade liberalization can be reaped only if this is accompanied by the right domestic policies in the realm of the macroeconomy, competitiveness and the compensation of critical market failures. This equally holds true for preferential liberalization.

The macroeconomic environment in which trade liberalization takes place is critical to its sustainability

${ }^{12}$ See Bouzas and Keifman (2003) for a more detailed discussion. and final impact. In Latin America there is a long tradition of trade liberalization programmes being implemented pari passu with macroeconomic stabilization processes built around the nominal exchange rate as an anti-inflationary anchor. All of them have led to appreciation of the domestic currency in real terms and, eventually, to external crises and policy reversals. These failures, occurring more than once in some countries, have weakened the productive fabric and reduced their ability to benefit from future episodes of trade liberalization. It is unlikely, furthermore, that economies subject to recurrent external shocks and volatile capital flows will be able to sustain successful trade liberalization policies over time while simultaneously achieving an acceptable growth performance.

In fact, countries will only manage an acceptable economic performance if they pursue export-oriented exchange-rate policies (preventing real appreciation of the domestic currency for long periods of time), implement prudent fiscal policies that avoid the buildup of excessive public-sector debt, and adopt mechanisms to offset unexpected shocks and turbulence. This being so, a preferential trade agreement which limits the scope for using policy instruments that can lessen a country's vulnerability to external shocks (originating, for example, in the financial markets) is unlikely to be the right recipe for responsible macroeconomic management. Conversely, one that includes compensatory mechanisms to deal with unexpected external shocks may increase the likelihood of more satisfactory macroeconomic 
outcomes. For example, there is a broad consensus that the rapid and massive financial help provided by the United States government to Mexico in 1994-1995 helped that country to leave the "peso crisis" behind it faster than it would otherwise have done. NAFTA probably had a favourable impact on investors' expectations, helping Mexico to overcome the crisis faster, but the financial package engineered by the United States Administration was at least as important at this time.

To bring about domestic conditions that will enable them to benefit from economic integration and trade liberalization, countries also need to implement policies that foster competitiveness and compensate for market failures. A more open trade regime is a necessary condition for greater economic efficiency, but other complementary policies that enable countries to reap the gains of international specialization are equally important. A competitiveness strategy of this kind should be based on at least three pillars: i) construction of adequate infrastructure; ii) diversification of the production structure, and iii) the development and strengthening of national innovation systems.

The lack of adequate infrastructure is one of the key factors holding back international trade. Many goods are not traded simply because high transport costs represent a major trade barrier. The relatively high prices of services also diminish the incentive to fragment the production process across countries, limiting the scope for intrasectoral specialization. Foreign aid could make a significant contribution to the upgrading of trade-related infrastructure by focusing on regional projects, or national projects with regional externalities. In North-South agreements, the issue of infrastructure development should be more easily and effectively addressed than in South-South agreements or unilateral or multilateral liberalization because one of the parties is usually well equipped with financial resources and administrative expertise that can be used for this purpose. The example of infrastructure spending in the European Union, where per capita income disparities are much smaller than in the Western Hemisphere, should encourage a more effective focus on this issue.

Export promotion policies can help to diversify production. Active trade diplomacy that opens up foreign markets, identifies new opportunities and disseminates information may help to increase exports. But to be effective these policies need a well trained bureaucracy and public-sector officials capable of developing a cooperative — but independentrelationship with the private sector. This suggests that there is a very significant role for export promotion policies focused on the provision of information, foreign trade support, financial assistance and insurance guarantees. Many of these instruments and institutions are already in place in a number of Latin American countries, but their efficacy is low. However, there are exceptions which confirm that their contribution really can be significant. Rather than conventional export subsidies (for the most part limited by multilateral commitments), a modern view of export promotion demands an emphasis on the efficient provision of information, coordination and other public goods.

Considering the failures that prevail in technology, credit and human capital markets, policies to increase productivity are the best recipe for better export performance in the long run. Although the Uruguay Round agreements prohibited non-agricultural export subsidies, they gave the green light to other domestic aids widely used by the industrial countries (such as subsidies for research and development). There are three aspects that are critical if the gap between industrial and developing countries as regards the type and extent of public-sector aids is to be closed (ECLAC, 2002). In the first place, policies should foster forward and backward linkages as a mechanism for rectifying a dualistic economic structure in which modern activities that are closely integrated into the world economy operate side by side with backward and low-productivity sectors. In this area, domestic public policies can help by providing infrastructure and coordination geared towards the strengthening of production clusters. Secondly, there must be official agencies in a position to help local firms (especially small and medium-sized ones) with technology diffusion, innovation and human resource development. Public policies should focus on providing a solid scientific and technological infrastructure, stimulating research and development and coordinating innovation activities undertaken by universities, research institutions and firms. Lastly, since research and development spending is about five times higher as a proportion of real output in the industrial countries than in developing ones, governments in the latter should consider granting research and development subsidies to the private sector.

None of these policies is guaranteed to succeed, particularly given the institutional fragility and weakness that prevail in Latin America. Even so, it is 
essential to undertake appropriate initiatives in each of these fields, if the objective is to reap the potential benefits of trade liberalization and economic integration. As the experience of Mexico after a decade in NAFTA demonstrates, despite rapid export growth to the United States market and the change in export composition, the lack of effective domestic policies in these critical areas has perpetuated a dual economy in which personal and regional income disparities have widened instead of contracting.

\section{IV}

\section{Ten years after Miami, where are FTAA negotiations heading?}

When the FTAA process was launched in 1994 it was received with a mixture of enthusiasm and scepticism. Both reactions were justified. Some governments regarded it as a way of restoring trade and investment incentives eroded by the preferences granted to Mexico, while others which did not see such obvious trade and investment incentives regarded it as an insurance policy that would guarantee stable access to a large market and as a mechanism to lock in economic reforms and improve expectations. Some governments saw the FTAA as an opportunity to strengthen hemispheric relations and make United States engagement in the region more explicit. These enthusiastic views account for the support that gathered around the initiative in many Latin American governments and the intense diplomatic efforts that many of them made to include trade issues on the agenda of the First Summit of the Americas, the presidential meeting held in Miami in December $1994 .{ }^{13}$

But the sceptics also had a point. Divergent agendas, interests and perceptions, asymmetries of development and size and the credibility problem faced by United States negotiators (lacking a Congressional mandate to negotiate trade agreements on a fast track basis) offered good reasons for pessimism. Despite these reservations, the more reluctant governments had little option but to follow the predominant trend. Consequently, they focused their efforts on strategies

\footnotetext{
13 A few weeks prior to this meeting, the United States Administration was inclined to exclude any specific trade commitments from the final declaration. Several governments in the region mobilized to change this decision, arguing that the failure to make an explicit commitment on trade would reduce the relevance of the Summit For an analysis of the early years of negotiations, see Bouzas and Svarzman (2001); see also Feinberg (1997).
}

to block or delay the negotiations. This was made easier for some time by the credibility deficit of the United States negotiators, but as time passed even the most reluctant parties started to prepare for substantive negotiations by organizing their public sectors and promoting closer cooperation between private and public actors. ${ }^{14}$

During the first three years of negotiations the participant governments gathered information, got to know each other and laid down the strategic principles that would guide the negotiations. Only at the Fourth Ministerial Meeting held in San Jose, Costa Rica in 1998 did the trade ministers announce the key principles and define the structure within which the negotiations would be carried on. ${ }^{15}$ However, the set of principles agreed at that time left several issues unresolved, enabling the parties to interpret commitments in different ways. ${ }^{16}$ The presidential meeting (Second Summit of the Americas) held in

\footnotetext{
${ }^{14}$ The Brazilian Government, one of the most reluctant participants in the FTAA process, was at the same time one of the most active in creating the domestic conditions it needed to negotiate effectively. See Da Motta Veiga (2002) for an analysis.

15 The main principles agreed were: i) consensus decision-making; ii) the agreement of a single package of rights and obligations valid equally for all signatories ("single undertaking"); iii) individual or group participation in the negotiations; iv) WTO-consistency; v) no a priori exclusions in market access negotiations; vi) the coexistence of the FTAA process with subregional integration processes; vii) equal rights and obligations, taking into consideration differences in size and development levels, and viii) the launching of effective negotiations in 1998 and conclusion by 2004 at the latest. At the San Jose meeting the parties agreed on the structure of the negotiations: there would be nine Negotiating Groups overseen by a Trade Negotiations Committee formed of deputy trade ministers. The Committee would meet at least once every 18 months.

${ }^{16}$ One example of the ambiguity of some of the principles agreed on at San Jose was the coexistence of the "single undertaking" and "early harvest" principles.
} 
Santiago, Chile in 1998 ratified the agreements reached in San Jose and formally launched the negotiations.

After Santiago the FTAA negotiations moved on to the next phase, with a more specific agenda that included mandates for each Negotiating Group and the specific procedures and modalities to be adopted in each forum. The parties agreed to write a unified draft text and submit it to the Sixth Meeting of Ministers of Trade scheduled to take place in Buenos Aires in April 2001. At that meeting the trade ministers examined a long "bracketed" text that consolidated the results achieved —or lack of them - in each of the nine Negotiating Groups. Much of the text simply reported divergent national positions.

The Seventh Meeting of Ministers of Trade took place in Quito in November 2002 and made modest progress with respect to the Buenos Aires meeting. In Quito a second draft text was submitted to the ministers, the Committee on Institutional Affairs began to operate and negotiating methods and procedures for the next phase were agreed upon (including the procedures for notifying base tariffs), as was a timetable for exchanging market access offers (starting on 15 December 2002). For all the apparent progress, in many chapters of the draft text only a few brackets, relating to formal aspects, were removed. Wherever text had been bracketed because of substantive differences of opinion, it remained so now.

The Quito Meeting of Ministers of Trade also raised doubts about the feasibility of the timetable, particularly when it came to the submission of market access offers. In fact, in five of the groups (agriculture, market access, government procurement, services and investment) market access negotiations were launched and a timetable for exchanging offers was set before critical differences over the methods and procedures to be adopted by each negotiating group had been bridged. The architecture of the services chapter and its relationship with the investment chapter, for example, were left unresolved. ${ }^{17}$ There was also disagreement over how tariff concessions should be submitted in the goods chapter. ${ }^{18}$ The operational

\footnotetext{
${ }^{17}$ It was left undecided, for example, whether offers in the services sector would be made following the criteria of negative or positive lists or whether offers on services-related foreign direct investment would be included in the investment or services chapter (the "commercial presence" modality, in the jargon of the General Agreement on Trade in Services). For a detailed discussion, see: http://www.ub.es/obsglob/Seriemercosur-.html.

${ }^{18}$ It was left undecided whether the presentation of market access offers in goods sectors would be made on the basis of the regional
}

content of the special and differential treatment principle was also a matter of controversy. ${ }^{19}$

The offers submitted since December 2002 reflect these ambiguities. In the goods and services chapters practically all countries had submitted offers by the target date (15 February 2003), but this was not the case with the investment and government procurement chapters. The groups of countries that submitted joint offers (Mercosur, the Andean Community and the Central American Common Market) did so with different formats, coverage and architectures, illustrating the difficulty of finding a common approach. The United States, meanwhile, submitted four different market access offers depending on the group of countries concerned. All other participants made a single offer, indicating the possibility of some type of special treatment for small economies. Services and investment offers were also made, following different architectural approaches.

In summary, just prior to the Eighth Meeting of Ministers of Trade, held in Miami in November 2003, the FTAA negotiations faced a large number of unresolved issues. The lack of offers from Argentina and Brazil in certain areas such as government procurement, services and investment reflected a growing preoccupation with the overall balance of the negotiations. In effect, the United States refusal to deal with certain issues at the hemispheric level (such as antidumping and agricultural subsidies), either because they were regarded as inappropriate for preferential treatment or systemic in nature, encouraged a response that consisted in the withdrawal from the FTAA agenda of issues considered to be of "offensive" interest to that country (precisely investment, services and government procurement). ${ }^{20}$ Consequently, in mid-2003 Mercosur formally submitted a proposal to continue negotiations along three parallel tracks: a bilateral track in the " $4+1$

most-favoured nation principle or would include differing treatment by country or group of countries. See: http://www.ub.es/obsglob/ Semercosur-.html.

${ }^{19}$ The Quito ministerial declaration reaffirmed some conditions for progress in the negotiations which made explicit the concerns prevalent among the participants. Major concerns were the need to make "continuous, balanced and substantial progress on all negotiating issues", to take into consideration differences in development level and size, and to link the FTAA negotiations to the progress made in the Doha round.

${ }^{20}$ Concerning the potential of the FTAA as a trigger for policy change in areas considered sensitive by the United States, it is telling that the Western Hemisphere countries which have not yet started bilateral preferential negotiations with the United States accounted in 2001 for slightly more than 6\% of United States exports, as compared to $44.3 \%$ for the hemisphere as a whole. 
format" (Mercosur member States and the United States), an FTAA track and a multilateral track. Each track would cover a different range of issues and the FTAA agenda would be considerably less ambitious than initially conceived. ${ }^{21}$

The reduction in the breadth and scope of the FTAA was complementary to another trend firmly established in recent years, namely the creeping "bilateralization" of the negotiating process. Since 1994 a multi-layered process of bilateral and "minilateral" negotiations, with access to the United States market a key consideration, has developed simultaneously with and in parallel to the FTAA process. As part of this process, and after a long delay, the United States Administration signed a free trade agreement with Chile and concluded negotiations with the members of the Central American Common Market. Negotiations were also launched with the Dominican Republic, Peru, Colombia, Ecuador and Bolivia. From the standpoint of United States interests, these sequential negotiations have aimed at gradually consolidating an agenda and an architecture consistent with broader United States negotiating objectives. The strategy has not been limited to the United States, though. Mercosur attempted with much less success to establish a free trade area in South America, while Mexico and Chile have succeeded in consolidating their role as hubs in the "hub and spokes" system under construction.

The Miami Meeting of Ministers of Trade did not clear up existing doubts about the prospects of the FTAA process, and indeed raised new ones. The summit was not an open failure, but it replicated a standard feature of FTAA negotiations: postponement of the most sensitive issues, even though the date set for concluding the negotiations was only 12 months ahead.

\footnotetext{
${ }^{21}$ See: http://www.ub.es/obsglob/Semercosur-.html. On that same occasion 13 countries (12 from Latin America plus Canada) submitted a document urging that an ambitious agenda be retained. Uruguay also presented a text that sought to reconcile the "original approach" with some degree of flexibility to accommodate national specificities.
}

In practice, the Miami meeting formalized what was already a fact, namely that the FTAA, if eventually agreed, will be considerably less ambitious than originally envisioned. This "light" version of the FTAA may serve the needs of several of the key parties, even if some of them formally oppose that architecture.

The Miami compromise ${ }^{22}$ — drafted by United States and Brazilian negotiators - gave rise to a twolayered agreement. The first layer includes "a common and balanced set of rights and obligations applicable to all signatories", while the second layer includes "additional benefits and obligations" for those countries or groups of countries willing to negotiate deeper market access commitments or stricter disciplines. The first and common layer would include rights and obligations in the nine areas under negotiation, with no exclusions. However, in the absence of an agreement to develop specific (and deeper) rules on all these issues, the resulting agreements may simply replicate the commitments already made at wTO. In that event, the WTO-plus nature of the FTAA process would be seriously open to question. The Ministerial Declaration also failed to go into any detail about the content of the general agreement, since the parties failed to reach consensus (a situation which remains unchanged as of late 2004).

The Ministerial Declaration did not clarify the relationship between the hemispheric agreement and the bilateral or plurilateral agreements either. One alternative could be to adopt an architecture similar to that of the pre-Uruguay Round GATT, whereby a multilateral agreement with rights and obligations for all signatories coexisted with voluntary codes of conduct. Another alternative could be a multilateral umbrella giving coverage to the existing network of bilateral and minilateral agreements. In this latter case the FTAA would resemble the architecture of the Latin American Integration Association (LAIA), with the major novelty of having the United States and Canada inside.

\footnotetext{
22 Ministerial Declaration of 20 November 2003 (Free Trade Area of the Americas, Eighth Meeting of Ministers of Trade, Miami).
} 


\section{V}

\section{Conclusions}

Although the negotiations have not concluded yet, the FTAA process demonstrates how difficult it is to negotiate reciprocal North-South preferential trade agreements. Indeed, the FTAA that is starting to emerge after a decade of negotiations is very problematic. The best guarantee of a more balanced and reciprocal agreement would have been to stick to negotiations undertaken within a "plurilateral" framework (the original spirit of the "single undertaking" concept). The asymmetries of the negotiating process, however, pushed it irreversibly in another direction.

After a decade of negotiations, the scenario of a balanced and comprehensive FTAA that offers an acceptable bargain to all the parties involved seems to be out of reach. This has been due to the nature of the agenda and the differences over how to deal with it (a number of parties have shown a limited interest in a comprehensive agreement). The interdependence between some of the issues under negotiation and the multilateral situation has made it unlikely that the former can move faster than the latter, unless a biased agenda prevails. In this context, as the United States Trade Representative stated after the failure of the wTо 2003 Ministerial Conference in Cancun, the United States is ready to move forward with its strategy of "competitive liberalization", reaching deals with partners that are ready for this. This scenario deepens the asymmetrical nature of hemispheric trade negotiations and reduces the likelihood of truly reciprocal trade agreements.

The most likely scenario for the FTAA is an agreement of limited coverage, along the lines of the "two-layered" architecture agreed in Miami. Given the difficulty of coming to terms on what should be included in the "umbrella" agreement, however, there is a very high chance that this will end up as an "ultralight" set of general principles. Such an agreement, however, may suit the interests of a larger number of partners than initially imagined.

Indeed, an "ultra-light" agreement would not run counter to the United States trade policy strategy of pursuing its trade agenda by the bilateral route. United States negotiators can continue to pick up those partners that offer the least resistance to their demands and whose own demands conflict least with the United States domestic political economy. This would enable them to continue promoting their trade objectives at a relatively low domestic political cost. For countries that have become hemispheric hubs, an "ultra-light" agreement may be a reasonable compromise to prolong the benefits of positive discrimination. In turn, the most reluctant partners (such as Brazil) may find that this scenario offers a way of putting off the tough choices implicit in a North-South agreement. This, however, must be weighed against the consequences of negative discrimination in Western Hemisphere markets and the resulting increase in the costs of exclusion. Over the medium term, this can hardly be regarded as an acceptable alternative unless the Doha Development Round makes unexpectedly substantial progress.

The complex trade architecture that will emerge in the Western Hemisphere is likely to exacerbate the mercantilist bias implicit in trade negotiations, making what is already a structurally asymmetrical playing field even less level. Considering the fragility of the disciplines governing preferential trade agreements at WTO, the prospects for North-South regionalism and its complementarity with the multilateral trading regime cannot but raise serious concerns.
Baldwin, R. (1993): A Domino Theory of Regionalism, Working Paper, No. 4465, Cambridge, Massachusetts, National Bureau of Economic Research.

Bhagwati, J. (1993): Regionalism and multilateralism: an overview, in J. de Melo and A. Panagariya (eds.), New Dimensions in Regional Integration, London, Centre for Economic Policy Research.

Bouzas, R. (2003): Mecanismos para compensar los efectos asimétricos de la integración regional y la globalización: el caso del MERCOSUR, document presented at the IDB Seminar on the Global and Local Challenges of Regional Development in Latin America and the Caribbean (Milan, March 2003).

Bouzas, R. and J. Ros (1994): The North-South variety of economic integration: issues and prospects for Latin America, in $\mathrm{R}$. Bouzas and J. Ros (eds.), Economic Integration in the Western Hemisphere, Notre Dame, University of Notre Dame Press. Bouzas, R. and S. Keifman (2003): Making trade liberalization work, in P.P. Kuczyinski and J. Williamson (eds.), After the 
Washington Consensus: Restarting Growth and Reform in Latin America, Washington, D.C., Institute for International Economics (IIE).

Bouzas, R. and G. Svarzman (2001): El área de libre comercio de las Américas: ¿dónde está y adónde va?, Boletín informativo Techint, No. 306, Buenos Aires, Organización Techint, April-June.

Da Motta Veiga, P. (2002): O policy-making da política comercial no Brasil: os caminhos da transição, El proceso de formulación de la política comercial. Nivel uno de un juego de dos niveles: estudios de países en el Hemisferio Occidental, Buenos Aires, Institute for the Integration of Latin America and the Caribbean (INTAL).

ECLAC (Economic Commission for Latin America and the Caribbean) (2002): Globalization and Development, LC/G.2157(SES.29/3), Santiago, Chile.

Ethier, W.J. (1998): The new regionalism, The Economic Journal, vol. 108, Oxford, Blackwell Publishing, July.

Feinberg, R. (1997): Summitry in the Americas, Washington, D.C., Institute for International Economics (IIE).

IDB (Inter-American Development Bank) (2002): Mas allá de las fronteras: el nuevo regionalismo en América Latina, Washington, D.C.
Lawrence, R. (1999): Regionalism, multilateralism, and deeper integration: changing paradigms for developing countries, in M. Rodríguez Mendoza, P. Low and B. Kotschwar (eds.), Trade Rules in the Making: Challenges in Regional and Multilateral Negotiations, Washington, D.C., Brookings Institution.

López Córdova, J.E. (2001): NAFTA and the Mexican Economy: Analytical Issues and Lessons for the FTAA, Buenos Aires, Institute for the Integration of Latin America and the Caribbean (INTAL)

Schiff, M. and A. Winters (2003): Regional Integration and Development, Washington, D.C., World Bank.

Torrent, R. (2002): Regional cooperation within the multilateral system of rules: Elements for a discussion from a legal, institutional and political perspective, document presented at the Workshop "The Evolving WTO Regime and Regional Economic Cooperation: Implications for Northeast Asia" (Seoul, Korea, 13-14 September), Korean Development Institute/Observatory of Globalization.

World Bank (2000): Trade Blocs, New York, Oxford University Press. 